\title{
OUTCOME PROGRAM BINA KELUARGA BALITA (BKB): KONSELING ORANG TUA DALAM TUMBUH KEMBANG ANAK USIA DINI
}

\author{
Islamiyah \\ STIKES Mandala Waluya Kendari \\ islamiyah.iis86@gmail.com \\ Faizah Binti Awad \\ Institut Agama Islam Negeri (IAIN) Kendari \\ izzahawad@gmail.com
}

\section{La Ode Anhusadar}

Institut Agama Islam Kendari (IAIN)

sadar.wanchines@gmail.com

\begin{abstract}
Abstrak
Penelitian ini dilakukan pada tahun 2017 atas kerjasama dengan BKKBN RI. Penelitian ini diharapkan mampu menghasilkan sebuah gambaran umum yang menjelaskan tentang fungsi dan tanggung jawab BKKBN wilayah Sulawesi Tenggara terhadap program bina keluarga balita PAUD yang telah di tetapkan. Sampel penelitian ini dipilih secara purposive sampling (Konawe dan Konawe Selatan). Sumber data yang akan digunakan yakni: data primer dan data sekunder. Teknik pengumpulan data yaitu wawancara, dokumentasi dan observasi. Penelitian ini menyimpulkan bahwa Keterlibatan orang tua dapat dilihat dari aspek outcome pelaksanaan bina keluarga balita telah memenuhi kriteria, hal ini dapat dilihat dari hasil yang diperolah dari penyelengaraan bina keluarga balita yang yang bisa menghasilkan orang tua yang kreatif, untuk evaluasi outcome dari bina keluarga balita menunjukkan adanya kreatifitas orang tua yaitu orang tua membuat sendiri alat permainan edukatif, orang tua menggunakan media di dalam rumah dan orang tua berhasil dan berprestasi.
\end{abstract}

Kata Kunci: Orang Tua, Tumbuh Kembang, dan Anak Usia Dini

\begin{abstract}
This research been conducted in 2017 in collaboration with the Republic of Indonesia to find out the bina keluarga balita outcame program in counseling parents in growing up with early childhood learning. The research sample selected by purposive sampling (Konawe and South Konawe). Data found from primary and secondary data. Data collection techniques are interviews, documentation and observation. Parental involvement can be seen from the aspect of the implementation of the outcome of bina keluarga balita meets the criteria, it can be seen from the results obtained from the
\end{abstract}


organization of bina keluarga balita that can generate creative parents. Results of evaluation of the outcome of the Program bina keluarga balita showed the creativity of parents that parents make their own means of educational games, parents are using media in the home and parents succeed and excel in applying good parenting as well as providing a good example to the community in applying the pattern foster true for children.

Keywords: Parents, Growth and Development, and Early Childhood

\section{Pendahuluan}

Upaya mencerdaskan anak sewajarnya dilakukan sedini mungkin, agar anak tumbuh dan berkembang sebagai individu yang cerdas baik secara intelektual, emosional maupun spiritual. Selanjutnya, secara dini pula orang dewasa (guru dan orang tua) perlu memahami dan membantu membimbing anak agar berbagai aspek perkembangan, seperti fase dan tugas perkembangan mereka dapat tumbuh dan berkembang secara optimal. Beberapa alasannya yaitu, pertama laporan hasil analisis tim education for all (Pendidikan untuk semua) indonesia tahun 2000, yang berpangkalan di departemen pendidikan nasional disebutkan bahwa pada tahun 2000 dari sekitar 26 juta anak Indonesia usia 0-6 tahun, lebih dari $80 \%$ anak Indonesia belum mendapatkan layanan pendidikan anak usia dini. Khususnya anak usia 4-6 tahun yang berjumlah 12 juta, baru sekitar 2 juta yang terlayani di Taman Kanak-kanak (TK) dan Raudatul Athfal (RA). Kedua, hasil penelitian yang menyebutkan bahwa masa usia dini adalah periode kritis dalam perkembangan anak. Hal ini telah dibuktikan dengan hasil penelitian di baylor college of medicine yang menemukan bahwa apabila anak jarang memperoleh rangsangan pendidikan maka perkembangan otaknya lebih kecil 20-30\% dari ukuran normal anak seusianya (Mubiar Agustin, 2014).

Menurut Eliasa mengkaji bagaimana teori kelekatan dari John Bowlby menjelaskan bahwa hubungan orang tua dengan anak akan bertahan cukup lama dalam rentang kehidupan manusia selanjutnya diawali dari kelekatan anak pada ibu. Bila sang anak mengalami kekurangan kasih sayang dari ibu, akan menyebabkan kecemasan, kemarahan, penyimpangan perilaku, dan depresi (Eliasa, 2011). Pada masa balita ini perkembangan kemampuan berbahasa, kreativitas, kesadaran sosial, emosional, dan intelegensia berjalan sangat cepat dan merupakan landasan perkembangan berikutnya. Perkembangan moral serta dasar-dasar kepribadian juga dibentuk pada masa ini. Pada 
masa periode emas ini, diperlukan rangsangan atau stimulasi yang berguna agar potensinya berkembang. Perkembangan anak akan optimal bila interaksi diusahakan sesuai dengan kebutuhan anak pada berbagai tahap perkembangannya, bahkan sejak bayi masih dalam kandungan (Nia Kania, 2006).

Pada msayarakat Sulawesi Tenggara yang masih banyak belum mengetahui tentang program bina keluarga balita, walaupun program bina keluarga balita tetap berjalan di beberapa lembaga PAUD. Namun penyelenggaraan pelayanan bagi anak usia dini tersebut masih bersifat sektoral, parsial dan belum terintegrasi dengan baik. Seharusnya pelayanan yang diberikan harus saling bersinergi dan mampu memenuhi kebutuhan dasar anak secara utuh baik dari segi perawatan, pendidikan, dan pengasuhan agar anak tumbuh kembang secara optimal. Program bina keluarga balita sebagai salah satu bentuk pelayanan anak usia dini yang bertujuan meningkatkan pengetahuan dan keterampilan orang tua dalam pengasuhan dan pembinaan tumbuh kembang anak, harus diintegrasikan dengan Program Layanan Anak Usia Dini yang lain, agar anak mendapatkan pelayanan secara utuh. Dari temuan studi hasil observasi awal yang kami lakukan menunjukkan bahwa pelaksanaan kelompok kegiatan bina keluarga balita belum optimal. Hasil pengamatan menunjukkan bahwa jumlah kader bina keluarga balita terbatas, kapasitas pengetahuannya yang masih rendah, pelatihan mengenai materi bina keluarga balita masih kurang, materi belum memadai. Namun, dengan pengintegrasian bina keluarga balita dengan kegiatan posyandu atau PAUD, kegiatannya menjadi lebih eksis. Dengan demikian pengintegrasian antara bina keluarga balita, Pos PAUD dan Posyandu dalam satu kegiatan yang terkoordinasi dan terintegrasi semakin memudahkan pemberian pelayanan dasar terhadap anak usia dini. Sehingga ini yang membuat kami tertarik untuk melakukan penelitian evaluasi program bina keluarga balita pada PAUD di Sulawesi Tenggara.

\section{Metode Penelitian}

Metode penelitian ini adalah penelitian kualitatif studi kasus. Penelitian ini diharapkan mampu menghasilkan sebuah gambaran umum yang menjelaskan tentang fungsi dan tanggung jawab BKKBN wilayah Sulawesi Tenggara terhadap Program bina bina keluarga balita yang telah di tetapkan. Sampel penelitian ini dipilih secara purposive sampling berdasarkan kelompok bina keluarga balita yang banyak dan mendapat bantuan 
anggaran dan memiliki kader bina keluarga balita yang berprestasi yaitu: Kota Konawe dan Kabupaten Konawe Selatan. Ada dua sumber data yang akan digunakan dalam penelitian ini yakni: Data Primer; adalah data yang diperoleh secara langsung dari informan dengan menggunakan wawancara. Data ini mencakup keadaan umum lokasi penelitian, keadaan geografis, keadaan demografis dan data-data yang berhubungan dengan penelitian ini. Teknik yang dapat digunakan untuk pengumpulan data dalam studi kasus dapat berupa : observasi, dokumentasi dan wawancara. Wawancara dilakukan dengan wawancara mendalam kepada para informan yaitu : Pengelola Program Provinsi: Kabid Keluarga Sejahtera, sekretaris badan, advokasi penggerakan dan informasi, Organisasi Perangkat Daerah Kab/Kota: KB, Diknas, dan Kesehatan, Lurah/Kepala Desa, PLKB: kader bina keluarga balita, PAUD, dan Posyandu dan FGD Ibu Balita. Pemilihan informan ini karena informan mempunyai informasi yang dibutuhkan oleh peneliti dan informan terlibat langsung dalam pelaksanaan program bina keluarga balita.

Evaluasi outcome dijadikan dasar untuk mengetahui keberadaan hasil program maupun sebagai dasar untuk memperbaiki proses pelaksanaan program. dalam pelaksanaan evaluasi keluaran ini selalu dikaitakan dengan sejauhmana dampak dari program hal ini di tandai dengan terciptannya orang tua yang kreatif dalam melakukan pola asuh yang benar dan adanya peningkatan jumlah peserta yang ikut berpartisipasi dalam program tersebut (Arifin, 2016).

\section{Kajian Teori}

Kognitif anak dapat berarti kecerdasan, berfikir, dan mengamati yang merupakan tingkah laku yang mengakibatkan anak mendapatkan pengetahuan. Apabila mengamati cara berfikir dan tingkah laku anak usia prasekolah, maka cara berfikir mereka termasuk semi logis, yaitu setengah masuk akal (pralogis). Keadaan ini oleh Piaget, seorang ahli psikologi kognitif, disebut tahap "praoperasional", yaitu suatu tahap di mana proses berfikir anak berpusat pada penguasaan simbol-simbol (misalnya, kata-kata) yang mampu mengungkapkan pengalaman masa lalu (Eti Nurhayati, 2012).

Deteksi dini perkembangan anak dapat dilakukan oleh orang tua dengan cara pemeriksaan perkembangan secara berkala sesuai dengan usia dari perkembangan anak. Menurt Kania ada 4 parameter yang dipakai dalam menilai perkembangan anak yaitu: 
gerakan motorik kasar (pergerakan dan sikap tubuh), gerakan motorik halus (menggambar, memegang suatu benda dll), bahasa (kemampuan merespon suara, mengikuti perintah, berbicara spontan), dan kepribadian/tingkah laku (bersosialisasi dan berinteraksi dengan lingkungannya) (Nia Kania, 2006). Berbagai macam stimulasi berupa stimulasi visual (penglihatan), verbal (bicara), auditif (pendengaran), taktil (sentuhan) dapat mengoptimalkan perkembangan anak. konseling dan stimulasi merupakan dua intervensi penting untuk memaksimalkan pertumbuhan dan perkembangan anak yang merupakan dua proses yang berbeda, tetapi saling terkait satu dengan lainnya (Darwati, Mexitalia, Hadiyanto, Hartanto, \& Nugraheni, 2014).

Dalam upaya penigkatan pencegahan penyimpangan tumbuh kembang anak balita dipandang perlu pemerataan program stimulasi pada deteksi dini dan intervensi dini tumbuh kembang anak balita dan pemantauan tumbuh kembang secara berkala.Tahap awal penapisan perkembangan dapat melibatkan orang tua sehingga setelah diketahui anak memerlukan evaluasi lebih lanjut untuk melakukan intervensi secara dini di tempat pelayanan kesehatan yang memadai. Adanya kerjasama antara keluarga yaitu orang tua, pengasuh anak dan anggota keluarga lainnya, masyarakat yaitu kader $\mathrm{BkkbN}$, organisasi profesi, dan lembaga swadaya masyarakat dengan tenaga professional akan memberikan kemudahan dalam penanganan penyimpangan tumbuh kembang pada anak, sehingga akan mengurangi dan memutus rantai ketidaknormalan pertumbuhan dan perkembangan anak balita (Fitriani \& Oktobriariani, 2017).

Orang tua/pengasuh dalam memberi pengasuhan pada usia dini, anak diajak meniru sesuatu yang sangat berkesan bagi mereka dan anak diajak untuk berpikir tentang ciptaan Tuhan dengan landasan kasih sayang. Pengenalan Tuhan bisa dikenalkan pada anak dengan doa yang sederhana, melalui bentuk ciptaan-ciptaan Tuhan yang dia kagumi. Jadi memberi pendidikan budi pekerti caranya sederhana, orang tua/pengasuh menyelami jiwa anak dan memberikan cinta kasih sayang setulus-tulusnya (Purnomo, 2013).

Keluarga adalah lembaga yang utama dan pertama bagi proses awal pendidikan anak-anak untuk mengembangkan potensi yang dimiliki seorang anak ke arah pengembangan kepribadian diri yang positif dan baik. Orang tua (ayah dan ibu) memiliki tanggung jawab yang besar dalam mendidik anak-anak dalam keluarga. Fungsi-fungsi dan peran orang tua tidak hanya sekedar memenuhi kebutuhan fisik anak berupa 
kebutuhan makan dan minum, pakaian, tempat tinggal tapi juga tanggung jawab orang tua jauh lebih penting dari itu adalah memberi perhatian, bimbingan, arahan, motivasi, dan pendidikan, serta penanaman nilai. Menurut Ki Hajar Dewantara, keluarga merupakan kumpulan individu yang memiliki rasa pengabdian tanpa pamrih, demi kepentingan seluruh individu yang bernaung di dalamnya. Begitu pentingnya keluarga dari kehidupan manusia bagi individu maupun sekelompok orang (Jailani, 2014).

Pendidikan saat ini menuntut adanya kolaborasi dengan berbagai pihak dalam berbagai kegiatan pendidikan. Kolaborasi adalah kegiatan dimana terjadi kerjasama antara berbagai pihak dalam mewujudkan tujuan- tujuan pendidikan, baik pihak dari dalam maupun dari luar lembaga pendidikan. Program bimbingan dan konseling sekolah juga menekankan adanya kolaborasi. Adapun kolaborasi dalam bimbingan itu sendiri melibatkan berbagai stakeholder, mulai dari kepala sekolah, wakil kepala sekolah, koordinator BK, guru BK, guru mata pelajaran, wali kelas, staf administrasi, komite sekolah sampai dengan orang tua. Orang tua sejatinya merupakan pendidik utama bagi siswa ketika berada di luar lingkungan sekolah. Orang tua terlibat dalam proses komunikasi timbal balik tentang program BK dan perkembangan peserta didik. Orang tua juga membantu dalam pengumpulan data dan informasi, serta membantu kesuksesan layanan BK dengan monitoring di luar sekolah. Berbagai peranan di atas menjadi kontribusi penting dalam penyelenggaraan program BK di sekolah secara efektif dan efisien. Sehingga berbagai keterlibatan orang tua di sekolah tersebut dapat memberikan dukungan serta hal positif bagi perkembangan siswa di sekolah (Nugraha \& Rahman, 2017). Menurut Ariyanti bahwa usia keemasan merupakan masa di mana anak mulai peka untuk menerima berbagai stimulasi dan berbagai upaya pendidikan dari lingkungannya baik disengaja maupun tidak disengaja. Pada masa peka inilah terjadi pematangan fungsifungsi fisik dan psikis sehingga siap merespon dan mewujudkan semua tugas- tugas perkembangan yang diharapkan muncul pada pola perilakunya sehari-hari (Tatik Ariyanti, 2016).

Pada anak usia dini mengalami pertumbuhan dan perkembangan yang sangat pesat sehingga membutuhkan stimulasi yang sesuai dengan kebutuhan anak-anak. Stimulasi tersebut salah satunya dapat diperoleh dari pendidikan anak usia dini. Pendidikan anak usia dini merupakan upaya pembinaan dan melalui pemberian rangsanagan pendidikan untuk meembantu pertumbuhan dan perkembangan jasmani dan 
rohani agar anak dapat memiliki kesiapan dalam memasuki pendidikan lebih lanjut (Suriati, Kuraedah, Erdiyanti, \& Anhusadar, 2019).

Peran orang tua dalam pengasuhan dan pembinaan tumbuh kembang anak sejak dini (0-6 tahun) atau periode emas sangat penting dan strategis dalam upaya mempersiapkan kualitas sumber daya manusia di masa yang akan datang. Layanan bina keluarga balita ini diperuntukkan bagi ibu yang memiliki balita. Layanan ini telah telah dikembangkan di beberapa negara, termasuk di Indonesia. Pendekatan Bina keluarga balita adalah melalui pendidikan orang tua khususnya ibu dan anggota keluarga lainnya. Bina keluarga balita secara kontinu menanamkan kepada orang tua agar tetap memperhatikan perkembangan anak secara komprehensif. Pada intinya setiap program yang diselenggarakan oleh bina keluarga balita menitik beratkan pada pengoptimalan fungsi-fungsi keluarga. dimana peranan fungsi tersebut bertujuan untuk menciptakan kondisi keluarga yang sejahtera (Setianingrum, Desmawati, \& Yusuf, 2017).

Upaya peningkatan kualitas dan kesejahteraan keluarga itu sendiri dilakukan pemerintah melalui pembinaan terhadap keluarga. Berdasarkan Undang-Undang nomor 52 Tahun 2009 Tentang Perkembangan Kependudukan dan Pembangunan Keluarga Pasal 47, mengamanatkan bahwa pemerintah dan pemerintah daerah menetapkan kebijakan pembangunan keluarga melalui pembinaan ketahanan dan kesejahteraan keluarga. Salah satu bagian dari program pembinaan ketahanan keluarga tersebut ialah bina keluarga balita (BKB). Bina keluarga balita merupakan salah satu program yang bertujuan untuk meningkatkan pemahaman dan keterampilan ibu dalam pengasuhan dan pendidikan anak (Fauziah, Mulyana, \& Raharjo, 2014).

Bina Keluaraga Balita adalah salah satu media pelayanan kesehatan yang memiliki berbagai jenis kegiatan yaitu penyuluhan dan bermain dengan Alat Permainan Eduaktif (APE). Upaya ini bertujuan untuk meningkatkan pengetahuan tentang kesadaran ibu dan anggota keluarga lainnya mengenai pentingnya proses tumbuh kembang balita serta meningkatkan keterampilan ibu dan anggota keluarga lainnya dalam mengusahakan tumbuh kembang anak secara optimal, antara lain stimulus mental dengan menggunakan Alat Permainan Edukatif (APE) dan memanfaatkan pelayanan yang tersedia (Visca Dwi Putrili, 2012). Bina keluarga balita adalah suatu kegiatan yang di laksanakan oleh masyarakat dengan tujuan untuk memberikan pengetahuan dan keterampilan kepada 
orang tua dan anggota keluarga lainnya tentang bagaimana melakukan pembinaan tumbuh kembang secara optimal anak balita serta bagaimana memantau pertumbuhan dan perkembangannya. Bina keluarga balita juga merupakan wahana bagi orang tua dan anggota keluarganya untuk meningkatkan kesadaran dan kemampuan keluarga dalam melakukan perawatan dan Pendidikan bagi anak-anaknya (Nur Khasanah; Khomsum Nurhalim, 2016)

Program bina keluarga balita merupakan gerakan bersama antara pemerintah dan masyarakat dengan ibu sebagai sasaran utama yang kaitannya dengan hantaran tumbuh kembang anak, deteksi dini kelainan atau kecacatan dan akhirnya menyiapkan anak balitanya siap sekolah bersama anak-anak lain. Keberadaan bina keluarga balita dapat dieksplorasi dalam rangka peningkatan pengetahuan, sikap, dan perilaku khususnya mengenai penggunaan antibiotika yang rasional pada Balita (Bela Mahardika, Suryawati, \& Aji, 2016).

\section{Hasil dan Pembahasan}

Evaluasi outcome aspek yang ingin dilihat adalah bagaimana pemahaman orang tua terhadap program bina keluarga balita, meningkatnya jumlah anggota yang aktif dalam program bina keluarga balita PAUD, pola asuh yang maksimal dari kepada balita dan berhasil meningkatkan dan menjaga tumbuh kembang anak agar tetap optimal memberikan motivasi kepada orang tua lain untuk ikut aktif dalam program bina keluarga balita paud dalam mewujudkan anak usia dini dengan tumbuh kembang yang optimal. Faktor pendukung kegiatan bina keluarga balita antara lain dari segi sasaran, partisipasi dan alat permainan tercukupi. Sedangkan faktor penghambatnya antara lain dari segi orang tua, dan keterbatasan kader (Setianingrum et al., 2017).

Motivasi yang dimaksud dalam penelitian ini adalah suatu yang mendorong serta menggerakkan orang tua dalam mengikuti program Bina keluarga balita. Timbulnya motivasi ada dua jenis yaitu dorongan dari luar diri orang-tua dan dari dalam pikiran diri orang tua itu sendiri tanpa ada pengaruh dari luar. Motivasi merupakan masalah yang sangat penting dalam setiap usaha manusia untuk mencapai suatu tujuan tertentu, setiap manusia tertentu mempunyaialasan dasar, mengapa para orang tua merasa sangat antusias dengan keberadaan bina keluarga balita, mengapa para orang tua mengikuti bina keluarga 
balita, mengapa ada orang tua yang sudah sangat puas dengan melihat perkembangan anak yang menjadi lebih baik setelah mengikuti program bina keluarga balita dan ada yang menerimanya dengan biasa saja.vTentulah semua ini ada dasar alasan yang mendorong dan menyebabkan orang tua mengikuti program bina keluarga balita.

Usia anak 0-6 tahun yang merupakan masa emas dimana anak akan berkembang dengan optimal di masa emas tersebut, sehingga harapan dari para orang tua yang menginginkan anaknya tumbuh dan berkembang secara optimal baik dari segi kognitif, afektif, psikomotorik dan juga dari segi sosialnya membuat orang tua mengikuti program bina keluarga balita. Program bina keluarga balita ini orang tua dibina untuk dapat merawat, mengasuh, dan mendidik anak-anaknya dengan cara yang benar, agar anak tersebut dapat tumbuh dan berkembang menjadi kebanggaan keluarganya sesuai dengan yang diharapkan. Motivasi intrinsik datang dari dalam hati sanubari umumnya karena kesadaran individu sendiri. Orang tua yang mempunyai balita datang ke tempat bina keluarga balita karena orang tua tersebut sadarbahwa dengan datang ke tempat bina keluarga balita maka orang tua akan mendapatkan pendidikan balita dimana akan diberikan materi tentang tahap-tahap pertumbuhan dan perkembangan anak dan akan dilihat apakah anak tersebut telah tumbuh dan berkembang sesuai dengan tahapan umurnya dan juga akan diberitahukan segala sesuatu yang berhubungan dengan anak balita, dengan begitu keinginan orangt ua agar anak dapat tumbuh dengan optimal dapat terpenuhi.

Motivasi intrinsik orang tua mengikuti kegiatan bina keluarga balita, salah satunya dengan adanya minat yang timbul dari dalam diri orang tua untuk mencari informasi mengenai pendidikan balita lebih mendalam dan juga mengikuti program bina keluarga balita. Dalam mengikuti program bina keluarga balita ini untuk dapat mengetahui bagaimana cara merawat, mengasuh, dan mendidik anak sejak usia dini dengan benar agar tidak salah asuh untuk perkembangan anak nantinya. Kebutuhan yang selalu ada dan harus dipenuhi oleh orang tua agar dapat memenuhi segala sesuatu yang berhubungan dengan pertumbuhan serta perkembangan anak agar dapat tumbuh dengan optimal sesuai dengan keinginan orang tua dan disini orang tua merasa setelah mengikuti bina keluarga balita perkembangan anak menjadi lebih baik dari sebelumnya, karena pada usia dini yaitu umur 0-6 tahun merupakan masa pertumbuhan dan perkembangan terbaik anak, jika tidak dibina dan diarahkan dengan baik maka anak akan mengalami gangguan 
di dalam pertumbuhan dan perkembangannya. Terlihat perbedaan anak yang orang tuanya mengikuti bina keluarga balita dan yang tidak mengikuti bina keluarga balita, karena orang tua yang mengikuti bina keluarga balita pasti lebih mengetahui tentang pendidikan balita, sehingga anak dapat tumbuh dan berkembang menjadi lebih baik sesuai dengan yang diharapkan keluarga terutama orang tua.

Motivasi instrinsik terjadi karena kesadaran diri sendiri, keinginan orang tua mengikuti Bina keluarga balita itu tanpa di pengaruhi oleh faktor lingkungan atau orang lain. Orang tua secara aktif sendiri mencari informasi-informasi pada saat berada di posyandu, karena itu orang tua tahu bahwa ada program bina keluarga balita untuk mengetahui bahwa pendidikan balita itu sangatlah penting, kemudian menyesuaikan dengan tujuan awal orang tua, jika yang dibutuhkan dapat dipenuhi oleh Bina keluarga balita akhirnya orang tua secara yakin mengikuti program bina keluarga balita.

Minat yang timbul dari dalam diri orang tua yaitu untuk mengetahui lebih banyak tentang pendidikan balita. Orang tua yang memiliki tingkat pendidikan yang rendah kurang dalam mengetahui proses pertumbuhan dan perkembangan anak yang baik dan sesuai dengan tingkat usia anak. Sehingga timbulnya minat dari dalam diri orang tua untuk dapat mengikuti program bina keluarga balita agar orang tua tersebut tidak salah asuh dalam merawat dan mendidik anak sejak usia dini, sehingga anak tersebut dapat tumbuh dengan optimal. Setiap kali membicarakan motivasi, hierarki kebutuhan Maslow pasti disebut-sebut.

Kebutuhan yang selalu ada dan timbul di dalam diri orang tua agar dapat merawat, mengasuh, dan mendidik anak-anaknya dengan cara yang benar menjadi sesuatu yang harus dipenuhi. Orang tua yang telah mengikuti program bina keluarga balita ini juga tidak perlu khawatir dengan proses pertumbuhan dan perkembangan anak balitanya, karena di dalam program bina keluarga balita ini para orang tua akan dibina agar dapat merawat, mengasuh, dan mendidik anak dengan benar, sehingga orang tua merasa aman serta orang tua juga dapat memberikan rasa aman dan nyaman dimana pun anak berada, karena orang tua adalah pelindung dan penjaga utama untuk anak. Seperti halnya yang diungkapkan oleh salah satu orang tua bernama Ibu Rani, berikut pernyataannya: "Dari yang saya ketahui jika anak seumur anak saya itu yang masih 2,5 tahun merupakan masa emas, jadi saya ingin agar anak saya dapat tumbuh dengan cerdas, pandai bergaul dan juga 
percaya diri, maka dari itu saya tidak ingin masa ini tidak terlewati begitu saja, sehingga saya ingin mengetahui bagaimana cara yang tepat untuk mengembangkan semuanya itu, agar anak saya dapat tumbuh dengan optimal (Wawancara dengan Ibu R, tanggal 13 Oktober 2017)."

Penjelasan di atas merupakan penuturan dari orang tua yang secara sadar akan berharganya masa emas anak, dan tidak ingin melewatkannya begitu saja. Masa emas yang dilalui anak umur 0-6 tahun ini tidak akan terulang kembali di masa selanjutnya. Anak balita yang dapat tumbuh dan berkembang dengan baik dan juga optimal yang sesuai dengan keinginan orang tuanya itu menjadi kebanggaan tersendiri untuk keluarga terutama orang tua dan juga para kader bina keluarga balita yang bangga melihat orang tua menjadi lebih baik dalam merawat dan mendidik anak-anaknya. Dalam kegiatan program bina keluarga balita ini orang tua dapat menambah wawasan serta dibina dalam tumbuh kembang anak balita dengan baik dan benar agar anak balita tersebut dapat tumbuh dan berkembang dengan optimal sesuai dengan harapan orang tua.

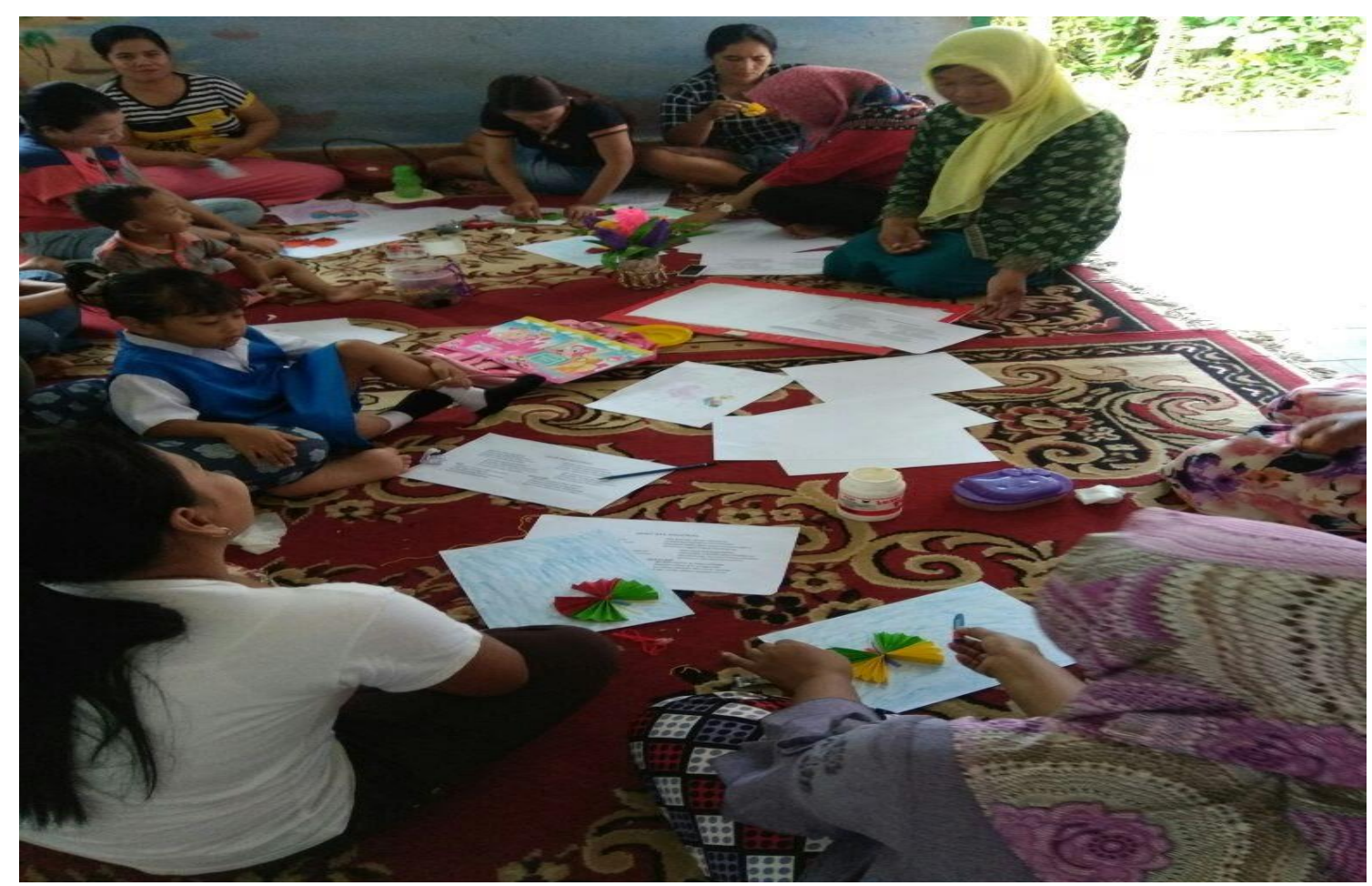

Gambar 1.

Kegiatan orang tua membuat media pembelajaran sambil menunggu anaknya.

Orang tua yang mengikuti bina keluarga balita bukan kehendak sendiri, tetapi karena dorongan dari orang lain seperti keluarga, teman, ataupun dari tetangga. Motivasi 
ekstrinsik yang datang dari luar diri orang tua umumnya datang dari pengaruh lingkungan, yaitu dorongan orang lain yang sangat berpengaruh untuk suatu kemajuan. Motivasi ekstrinsik ini muncul dari luar diri sendiri, sehingga orang lain sangat berpengaruh dalam mendapatkan sesuatu yang ingin dicapai. Terdapat orang tuayang mengikuti bina keluarga balita karena adanya dorongan dari tetangga yang peduli dengan pendidikan balita agar orang tua tersebut tidak salah asuh. Seperti halnya yang diungkapkan oleh salah satu orang tua bernama Ibu Siti Fatimah, berikut pernyataannya: "Saya mengikuti bina keluarga balita ini salah satunya, memang karena tetangga saya yang tahu bahwa saya baru mempunyai anak dan belum ada pengalaman dalam mengurus anak jadi saya diberi tahu untuk ikut bina keluarga balita supaya dapat mengetahui bagaimana proses tumbuh kembang anak yang baik itu sesuai dengan umurnya biar saya tidak salah dalam mendidik dan mengasuh anak saya" (Wawancara dengan Ibu SF, tanggal 13 Oktober 2017).

Penjelasan di atas merupakan penuturan dari salah satu orang tua yang mendapatkan dorongan dari tetangganya agar dapat mengikuti bina keluarga balita. Pengalaman yang baru saja mempunyai anak sehingga masih butuh saran dan bimbingan dari pihak lain mengenai dunia anak balita yang salah satunya bisa di dapatkan di bina keluarga balita. orang tua yang mengikuti bina keluarga balita karena adanya pengaruh lingkungan yang timbul dari luar diri orang tua yaitu timbul dorongan dari para tetangga yang peduli dengan pendidikan anak balita agar orang tua yang memiliki balita dapat mengikuti program bina keluarga balita untuk dapat mengetahui bahwa proses pertumbuhan dan perkembangan anak sangatlah penting untuk dipahami dan dimengerti secara lebih mendalam. Karena adanya dorongan dari tetangga maka orang- tua yang memiliki anak balita mengikuti program bina keluarga balita agar tidak salah dalam merawat dan mendidik anak sejak dini. 


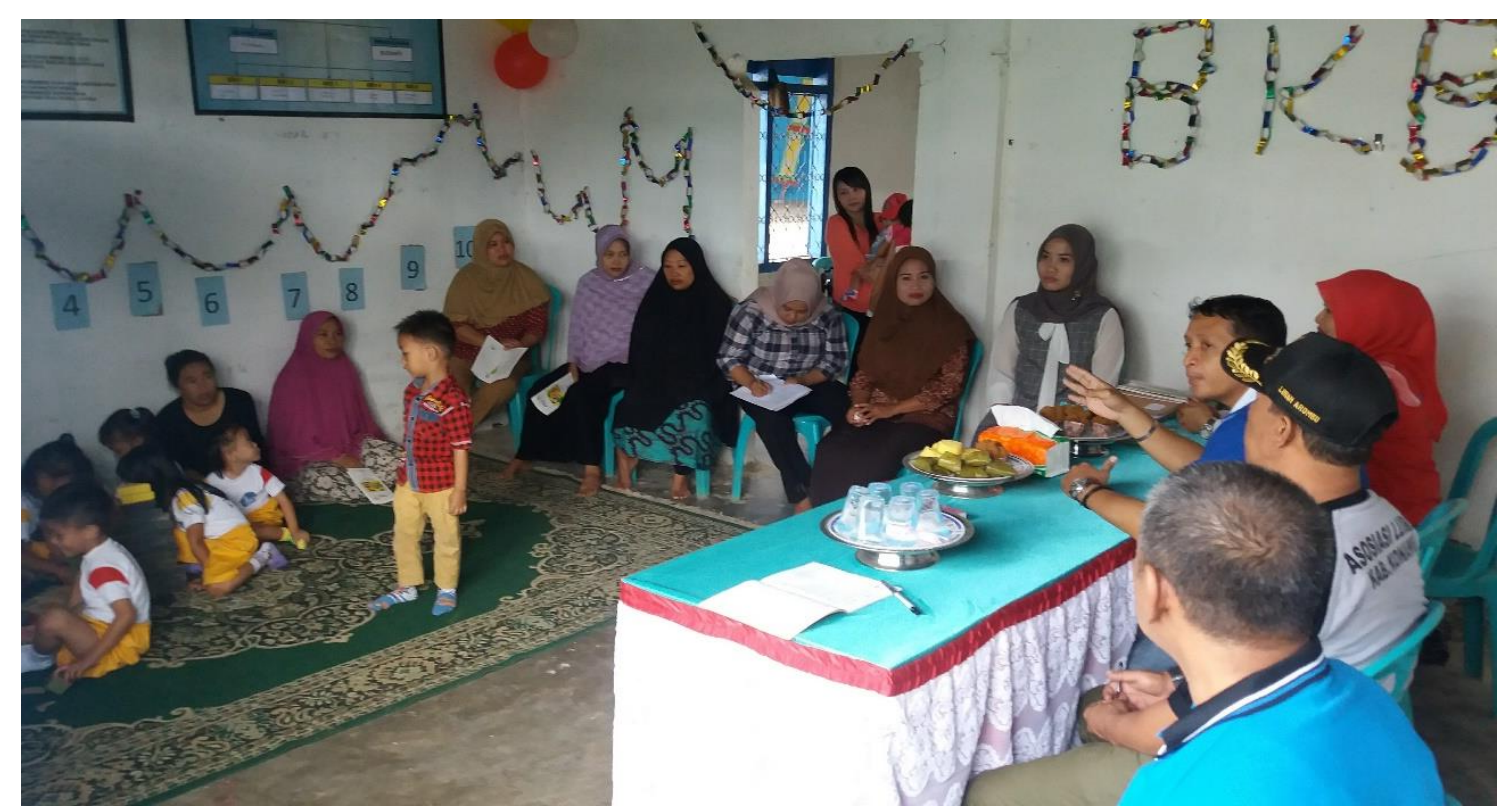

\section{Gambar 2.}

Kegiatan BKB dengan Posyandu, orang tua mendapatkan materi tumbuh kembang anak.

Salah satu faktor penghambat dari dalam diri orang tua dalam mengikuti bina keluarga balita adalah pada saat orang tua yang mempunyai banyak pekerjaan rumah yang tidak bisa ditinggalkan, sehingga tidak dapat mengikuti kegiatan Bina keluarga balita. Seperti halnya yang diungkapkan oleh salah satu orang tua bernama Ibu Lilik, berikut pernyataannya: "Saya sebagai ibu rumah tangga mbak, jadi banyak sekali pekerjaan rumah yang harus saya kerjakan dan terkadang karena banyaknya pekerjaan rumah yang harus saya kerjakan jadi saya tidak mengikuti bina keluarga balita karena saya takut jika suami saya pulang kerja nanti, ternyata pekerjaan rumahnya belum selesai, jadi saya lebih memilih menyelesaikan pekerjaan rumah saya terlebih dahulu (Wawancara dengan Ibu L tanggal 13 Oktober 2017).”

Penjelasan di atas merupakan penuturan dari orang tua yang tidak dapat mengikuti program bina keluarga balita karena harus mengerjakan pekerjaan rumah tangga. Karena pekerjaan rumah tangga merupakan tanggung jawab orang tua terutama ibu untuk mengerjakannya. Sedangkan, faktor penghambat dari luar diri orang tua dalam mengikuti bina keluarga balita adalah sarana dan prasarana yang masih kurang memadai untuk keberlangsungan kegiatan bina keluarga balita ini. Semua orang tua yang menjadi subjek penelitian yang ada lima subjek menjawab bahwa sarana dan prasarana kurang memadai untuk para kader bina keluarga balita dan juga untuk para orang tua. 
Faktor penghambat yang timbul dari dalam diri orang tua yaitu karena belum dapat membagi waktu untuk dapat mengikuti kegiatan di luar rumah. Pekerjaan rumah tangga yang tidak sedikit membuat orang tua sibuk di dalam rumahnya sendiri. Faktor penghambat dari luar diri orang tua yaitu dari fasilitas di gedung posyandu yang sekaligus dipakai untuk kegiatan bina keluarga balita. Fasilitas yang masih kurang memadai membuat orang tua menjadi kurang nyaman dalam mengikuti kegiatan bina keluarga balita. Seperti halnya yang diungkapkan oleh salah satu orang tua bernama Ibu M berikut pernyataannya: "Di bina keluarga balita ini, menurut saya sarana dan prasarananya itu masih kurang, seperti meja dan kursi. Jadi kadang ibu-ibu yang datang itu duduknya lesehan di bawah dan ada ibu-ibu yang gak kuat duduk di bawah terlalu lama karena kakinya suka kram.” Penjelasan ini merupakan penuturan dari orang tua yang merasa bahwa sarana dan prasarana di tempat bina keluarga balita ini masih kurang memadai. Perlu lebih di perhatikan lagi sarana dan prasarananya agar orang tua yang mengikuti program bina keluarga balita tersebut merasa nyaman.

Hasil dari evaluasi outcome, dapat dilihat dari aspek outcome pelaksanaan bina keluarga balita telah memenuhi kriteria, hal ini dapat dilihat dari hasil yang diperolah dari penyelengaraan bina keluarga balita yang yang bisa menghasilkan orang tua yang kreatif, untuk evaluasi outcome dari program bina keluarga balita menunjukkan adanya kreatifitas orang tua yaitu orang tua membuat sendiri alat permainan edukatif, orang tua menggunakan media di dalam rumah dan orang tua berhasil dan berprestasi dalam menerapkan pola asuh yang baik serta memberikan contoh yang baik kepada masyarakat dalam menerapkan pola asuh yang benar bagi anak. Begitu juga dari hasil penelitian didapat bahwa prestasi orang tua di masyarakat lebih baik dibandingkan dengan orang tua yang tidak mengikuti program bina keluarga balita, hal ini dapat dilihat dari meningkatnya jumlah anggota yang aktif dalam program bina keluarga balita PAUD, memberikan pelayanan pola asuh yang maksimal dari kepada balita, berhasil meningkatkan dan menjaga tumbuh kembang anak agar tetap optimal dan memberikan motivasi kepada orang tua lain untuk ikut aktif dalam program bina keluarga balita PAUD. Selain itu interaksi alumni kader dan pengelola dengan masyarakat setempat masih berjalan dengan baik hal ini dapat dilihat dari masyarakat mendukung dan membantu program bina keluarga balita PAUD, masyarakat semakin banyak yang ikut berkonstribusi dalam program bina keluarga balita PAUD dan alumni dan masyarakat 
saling mendukung dalam membuat sarana pembelajaran pendukung program bina keluarga balita PAUD. Untuk mempermudah penjelasan hasi dari evaluasi outcome akan di jabarkan pada tabel berikut ini :

\begin{tabular}{llcc}
\hline No & Outcome & \multicolumn{2}{c}{ BINA KELUARGA BALITA } \\
\cline { 3 - 4 } & & \multicolumn{2}{c}{$\begin{array}{c}\text { Tidak } \\
\text { Meningkat }\end{array}$} \\
\hline 1 & Kreatifitas orang tua & $\sqrt{ }$ & \\
\hline 2 & $\begin{array}{l}\text { Prestasi orang tua di } \\
\text { masyarakat }\end{array}$ & $\sqrt{ }$ \\
\hline 3. & $\begin{array}{l}\text { Interaksi alumni kader dan } \\
\text { pengelola dengan masyarakat } \\
\text { setempat }\end{array}$ & $\sqrt{ }$ \\
\hline
\end{tabular}

Dari data diatas dapat disimpulkan bahwasanya outcome program yang dilaksanakan baik bina keluarga balita bila dilihat dari meningkatkan kreatifitas orang tua peserta bina keluarga balita dalam termasuk dalam katagori baik dan dilihat prestasi orang tua di masyarakat kategori baik serta interaksi alumni kader dan pengelola dengan masyarakat setempat berjalan dengan sangat baik. Sehingga bila dilihat dari indikator masing-masing termasuk dapat dikatagorikan dalam katagori sangat baik. Partisipasi orang tua pada kegiatan bina keluarga balita dapat dikatakan tinggi karena dilihat dari rutin nya menghadiri kegiatan bulanan bina keluarga balita yang pada pelaksanaannya kegiatan bulanan tersebut termasuk pada kegiatan penyuluhan dan penimbangan balita, selain itu orang tua anggota kegiatan bina keluarga balita memiliki kemauan untuk bertanya mengenai informasi kegiatan bina keluarga balita yang akan dilakukan kepada kader bina keluarga balita ataupun saling memberikan informasi kepada sesama anggota bina keluarga balita lainnya. 


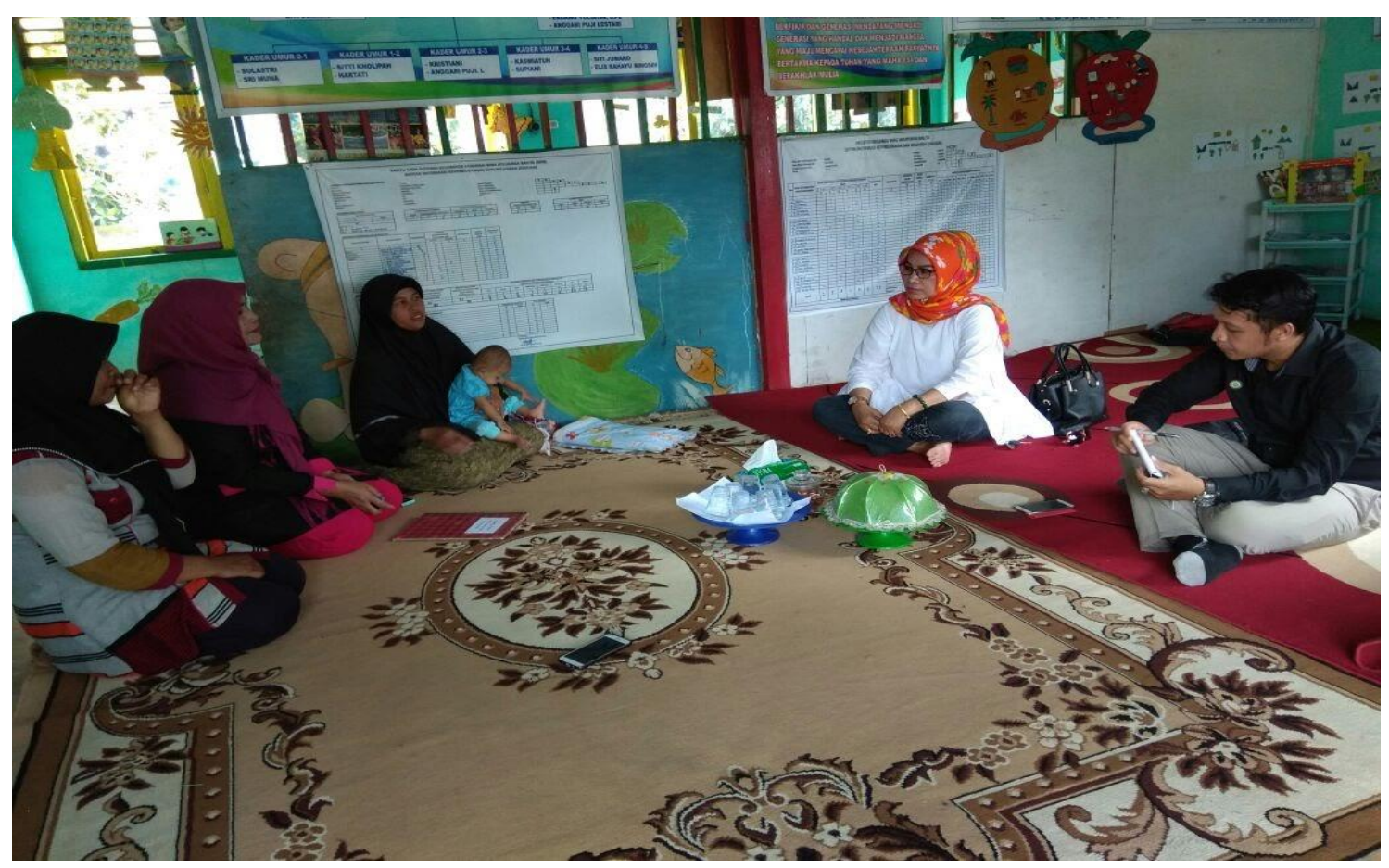

Gambar 3.

Kegiatan ruin orang tua di $\mathrm{BKB}$

Stimulasi tumbuh kembang balita yang dilakukan oleh orang tua yang berpartisipasi pada kegiatan bina keluarga balita dapat dikatakan baik karena stimulasi yang dilakukan oleh orang tua sudah memenuhi kebutuhan dasar anak asuh, asih, dan asah dilihat dari pemenuhan kebutuhan kesehatan dan gizi pada balita oleh orang tua, kasih sayang yang diberikan oleh orang tua terhadap balita nya dan stimulasi tumbuh kembang balita yang sesuai dengan tujuh aspek perkembangan anak yaitu stimulasi gerakan kasar, stimulasi gerakan halus, stimulasi komunikasi pasif, stimulasi komunikasi aktif, stimulasi kecerdasan, stimulasi kemampuan menolong diri sendiri, stimulasi kemampuan bergaul dan tingkah laku social (Pratama, 2017).

\section{Penutup}

Keterlibatan orang tua dapat dilihat dari aspek outcome pelaksanaan bina keluarga balita telah memenuhi kriteria, hal ini dapat dilihat dari hasil yang diperolah dari penyelengaraan bina keluarga balita yang yang bisa menghasilkan orang tua yang kreatif, untuk evaluasi outcome dari program bina keluarga balita menunjukkan adanya kreatifitas orang tua yaitu orang tua membuat sendiri alat permainan edukatif, orang tua menggunakan media di dalam rumah dan orang tua berhasil dan berprestasi dalam 
menerapkan pola asuh yang baik serta memberikan contoh yang baik kepada masyarakat dalam menerapkan pola asuh yang benar bagi anak. Evaluasi outcome program yang dilaksanakan baik bina keluarga balita bila dilihat dari meningkatkan kreatifitas orang tua peserta bina keluarga balita termasuk dalam katagori baik dan dilihat prestasi orang tua di masyarakat kategori baik serta Interaksi alumni kader dan pengelola dengan masyarakat setempat berjalan dengan sangat baik. Sehingga bila dilihat dari indikator masing-masing termasuk dapat dikatagorikan dalam katagori sangat baik.

\section{DAFTAR PUSTAKA}

Arifin, Z. (2016). Evaluasi pembelajaran: Prinsip, teknik, dan prosedur. Bandung: PT Remaja Rosdakarya.

Bela Mahardika, A., Suryawati, S., \& Aji, R. (2016). Intervensi CBIA untuk Meningkatkan Pengetahuan, Sikap, dan Perilaku Penggunaan Antibiotik yang Rasional pada Anggota Bina Keluarga Balita. Jurnal Kedokteran Brawijaya, 29(2), 165-169. https://doi.org/10.21776/ub.jkb.2016.029.02.11

Darwati, D., Mexitalia, M., Hadiyanto, S., Hartanto, F., \& Nugraheni, S. A. (2014). Pengaruh Intervensi Konseling Feeding Rules dan Stimulasi Terhadap Status Gizi dan Perkembangan Anak di Posyandu Kabupaten Jayapura. Sari Pediatri, 15(6), 377-384. https://doi.org/10.14238/sp15.6.2014.377-84

Eliasa, E. I. (2011). Pentingnya kelekatan orang tua dalam internal Working model untuk pembentukan karakter anak. Developmental Psychology, 33(5), 806-821.

Eti Nurhayati. (2012). Memahami Tumbuh Kembang Anak Usia Dini. Society, 1-14.

Fauziah, R., Mulyana, N., \& Raharjo, S. T. (2014). Efektifitas Program Bina Keluarga Balita. Share: Social Work Journal, 4(1), 59-68. https://doi.org/10.24198/share.v4i1.13059

Fitriani, I. S., \& Oktobriariani, R. R. (2017). Stimulasi, Deteksi dan Intervensi Dini Orang Tua terhadap Pencegahan Penyimpangan Pertumbuhan dan Perkembangan Anak Balita. Indonesian Journal for Health Sciences, 1(1), 1-9. https://doi.org/10.24269/ijhs.v1i1.2017.pp10-16

Jailani, M. S. (2014). Teori Pendidikan Keluarga dan Tanggung Jawab Orang Tua dalam Pendidikan Anak Usia Dini. Nadwa, 8(2), 245. https://doi.org/10.21580/nw.2014.8.2.580

Mubiar Agustin. (2014). Hakikat Bimbingan dan Konseling untuk Anak Usia Dini. UT (Vol. 1). Jakarta. from file:///C:/Users/User/Downloads/Documents/PAUD4406-M1_2.pdf

Nia Kania. (2006). Stimulasi Tumbuh Kembang Anak Untuk Mencapai Tumbuh Kembang Yang Optimal (pp. 1-10). Bandung. 
Nugraha, A., \& Rahman, F. A. (2017). Strategi Kolaborasi Orang tua Dengan Konselor Dalam Mengembangkan Sukses Studi Siswa. Jurnal Konseling GUSJIGANG, 3(1), 128-136.

Nur Khasanah; Khomsum Nurhalim. (2016). Motivasi Orang tua Dalam Mengikuti Program Bina Keluarga Balita Di Kelurahan Uwung Jaya Kota Tangerang. Journal of Nonformal Education and Community Empowerment, 5(1), 9-15.

Pratama, D. (2017). Dampak Partisipasi Orang Tua Dalam Kegiatan Bina Keluarga Balita Terhadap Proses Stimulasi Tumbuh Kembang Balita (Studi pada Keluarga Peserta BKB Flamboyan Rw 03 Kelurahan Cigugur Tengah Kecamatan Cimahi Tengah). Jurnal Pendidikan Luar Sekolah, 13(2), 42-52.

Purnomo, H. (2013). Peran Orang Tua dalam Optimalisasi Tumbuh Kembang Anak untuk Membangun Karakter Anak Usia Dini. Prosiding Seminar Nasional Parenting, 34-47.

Setianingrum, S., Desmawati, L., \& Yusuf, A. (2017). Peranan Kader Bina Keluarga Balita dalam Optimalisasi Tumbuh Kembang Fisik Motorik Anak Usia Dini. Journal of Nonformal Education and Community Empowerment, 1(2), 137-145. https://doi.org/10.15294/pls.v1i2.13891

Suriati, S., Kuraedah, Erdiyanti, L. O., \& Anhusadar. (2019). Meningkatkan Keterampilan Motorik Halus Anak melalui Mencetak dengan Pelepah Pisang. Jurnal Obsesi: Jurnal Pendidikan Anak Usia Dini, 4(1), 211. https://doi.org/10.31004/obsesi.v4i1.299

Tatik Ariyanti. (2016). Pentingnya Pendidikan Anak Usia Dini Bagi Tumbuh Kembang Anak. Jurnal Dinamika Pendidikan Dasar, 8(1), 50-58. https://doi.org/10.2320/materia.46.171

Visca Dwi Putrili. (2012). Praktik Pengasuhan Anak Pada Keluarga Petani Peserta Bina Keluarga Balita (BKB) Melati 3 Di Desa Nguken Kecamatan Padangan Kabupaten Bojonegoro. Indonesian Journal of Early Childhood, 2(2), 50-57. https://doi.org/10.15294/IJECES.V1I2.9211 